University of Nebraska - Lincoln

DigitalCommons@University of Nebraska - Lincoln

USDA National Wildlife Research Center - Staff Publications
U.S. Department of Agriculture: Animal and Plant Health Inspection Service

2014

\title{
Invasive black spiny-tailed iguanas (Ctenosaura similis) on Gasparilla Island, Florida, USA
}

\author{
Michael L. Avery \\ United States Department of Agriculture, michael.I.avery@aphis.usda.gov \\ Eric A. Tillman \\ USDA/APHIS/WS National Wildlife Research Center, eric.a.tillmann@aphis.usda.gov \\ Conny Spurfeld \\ USDA/APHIS/WS National Wildlife Research Center \\ Richard M. Engeman \\ USDA-APHIS-Wildlife Services, s_r100@yahoo.com \\ Kelin P. Maciejewski \\ United States Department of Agriculture
}

See next page for additional authors

Follow this and additional works at: https://digitalcommons.unl.edu/icwdm_usdanwrc

Part of the Life Sciences Commons

Avery, Michael L.; Tillman, Eric A.; Spurfeld, Conny; Engeman, Richard M.; Maciejewski, Kelin P.; Brown, Jessica D.; and Fetzer, Emily A., "Invasive black spiny-tailed iguanas (Ctenosaura similis) on Gasparilla Island, Florida, USA" (2014). USDA National Wildlife Research Center - Staff Publications. 1454.

https://digitalcommons.unl.edu/icwdm_usdanwrc/1454

This Article is brought to you for free and open access by the U.S. Department of Agriculture: Animal and Plant Health Inspection Service at DigitalCommons@University of Nebraska - Lincoln. It has been accepted for inclusion in USDA National Wildlife Research Center - Staff Publications by an authorized administrator of DigitalCommons@University of Nebraska - Lincoln. 


\section{Authors}

Michael L. Avery, Eric A. Tillman, Conny Spurfeld, Richard M. Engeman, Kelin P. Maciejewski, Jessica D. Brown, and Emily A. Fetzer 


\title{
ORIGINAL ARTICLE
}

\section{Invasive black spiny-tailed iguanas (Ctenosaura similis) on Gasparilla Island, Florida, USA}

\author{
Michael L. AVERY, ${ }^{1}$ Eric A. TILLMAN, ${ }^{1}$ Conny SPURFELD, ${ }^{2}$ Richard M. ENGEMAN, ${ }^{3}$ Kelin P. \\ MACIEJEWSKI, ${ }^{1}$ Jessica D. BROWN ${ }^{4}$ and Emily A. FETZER ${ }^{1}$ \\ ${ }^{1}$ United States Department of Agriculture, Wildlife Services (USDA-WS), National Wildlife Research Center, Florida Field Station, \\ Gainesville, Florida, USA, ${ }^{2}$ USDA-WS, Gainesville, Florida, USA, ${ }^{3}$ USDA-WS, National Wildlife Research Center, Fort Collins, \\ Colorado USA and ${ }^{4}$ Berryman Institute, Mississippi State University, Starkville, Mississippi, USA
}

\begin{abstract}
The native range of Ctenosaura similis extends from southern Mexico through Panama. From an initial introduction of 3 animals in 1979, the species now numbers in the thousands on Gasparilla Island in southwest Florida. In response to complaints of property damage from residents and threats to native species, local officials and the US Department of Agriculture Wildlife Services began a removal program in 2008. Through 2011, trappers removed 9467 ctenosaurs. The number removed declined from 32 iguanas/day in 2008 to 1.9 iguanas/day in 2011 despite no easing of the control effort. We necropsied 2757 ctenosaurs to document aspects of their natural history. Females outnumbered males overall, although the largest size class ( $>300 \mathrm{~mm}$ snout-vent length) included 32 males and just 2 females. Reproduction was seasonal. We found oviducal eggs in females from early Apr to early Jun, approximately 2 months later than $C$. similis in its native range. We trapped hatchlings from late Jul to early Oct coincident with the summer rainy season. Clutch size increased with female body size, with 62 being the largest clutch size recorded. In general, the biology of the invasive population on Gasparilla Island resembles native $C$. similis populations in Central America, except for the lack of large individuals. We suggest that shorter day length and colder temperatures create environmental conditions that are suboptimal for individual growth compared to those in the native range.
\end{abstract}

Key words: Ctenosaura similis, Florida, invasive reptile, population control, spiny-tailed iguana

Correspondence: Michael L. Avery, USDA/Wildlife Services, National Wildlife Research Center, Florida Field Station, 2820

East University Avenue, Gainesville, FL 32641, USA.

Email: michael.1.avery@aphis.usda.gov

\section{INTRODUCTION}

Ctenosaura similis (Gray, 1830) occurs naturally throughout southern Mexico and Central America, where it is widely exploited for its purported medicinal properties and as a food source (Fitch \& Hackforth-Jones 1983; Savage 2002; Stephen et al. 2011). This species is also part of the international pet trade. 
During 2001-2008, approximately 13000 were imported into the USA. This practice has declined in recent years, and only 78 were imported in 2008 (Stephen et al. 2011). C. similis was first released in Florida in 1979 when a resident brought 3 animals from southern Mexico and liberated them on the southern end of Gasparilla Island, Lee County (Krysko et al. 2003). A recent genetic analysis showed that the current Gasparilla Island population is most closely allied with $C$. similis populations in Nicaragua, Costa Rica and Honduras, and not as closely allied with those from Mexico (L. Buckley, Rochester University, unpubl. data).

In Florida, 56 species of introduced reptiles and amphibians are now established, including 43 lizard species (Krysko et al. 2011a). C. similis breeds throughout Gasparilla Island and on the adjacent mainland. The species seems to be most widespread in southwestern Florida, but populations are also established along Florida's southeastern coast and on the Florida Keys (Townsend et al. 2003; Krysko et al. 2011b; Meshaka 2011). The species has tremendous reproductive potential, with a single annual clutch containing 12-88 eggs $($ mean $=43)($ Fitch \& Hackforth-Jones 1983), with an invasive female reported to have 82 oviducal eggs on Key Biscayne (Krysko et al. 2003).

Gasparilla Island has become increasingly developed with residential communities since the introduction of C. similis in 1979. Such land use changes are compatible with the natural history of the species; in its native range, $C$. similis is abundant in human-altered environments (Fitch \& Henderson 1978). This adaptability, refugia and nest sites (provided by gopher tortoise burrows), and minimal human persecution have created a situation in which the $C$. similis population can easily persist and expand.

On Gasparilla Island, C. similis eats expensive landscape plantings and invades houses, causing monetary damage and aggravating homeowners (Reed 2006). In addition to creating problems for residents, the species also threatens sensitive native flora and fauna (Krysko et al. 2003). Although these iguanas are primarily herbivorous, they will opportunistically eat other lizards, small birds, rodents and invertebrates (Fitch \& Hackforth-Jones 1983), and we have documented them to eat juvenile gopher tortoises [Gopherus polyphemus (Daudin, 1802)] (Avery et al. 2009). There is also the possibility of iguanas preying on various Florida bird species, such as the least tern (Sternula antillarum Lesson, 1847), the snowy plover [Charadrius nivosus (Cassin, 1858)] and the burrowing owl [Athene cunicularia floridana (Ridgway, 1874)] (Krysko et al. 2003). Fur- thermore, $C$. similis feeds on the same native plants as the gopher tortoise, potentially depriving the tortoises of food resources, and iguanas usurp gopher tortoise burrows, potentially compromising the tortoises' reproductive success (McKercher 2001; Krysko et al. 2003; Engeman et al. 2009).

Gasparilla Island comprises 2 separate jurisdictions, Lee County and Charlotte County. In response to steadily increasing numbers of iguanas, in 2007 Lee County residents hired a private trapper to remove iguanas from that county's part of Gasparilla Island. In 2008, Charlotte County residents contracted the US Department of Agriculture Wildlife Services to remove iguanas and that effort continued through 2011. A concurrent removal effort continued in Lee County, but we are not privy to those results. Many of the iguanas taken in Charlotte County during 2008-2011 were sent to the US Department of Agriculture wildlife research facility in Gainesville for necropsy, and we report on those findings here. Our objectives were to describe the general biology of this invasive population, to document temporal changes within the population and to compare the invasive population with published information from a portion of the native range, specifically Costa Rica and Nicaragua, corresponding to the putative origin of the invasive population.

\section{MATERIALS AND METHODS}

\section{Study area}

Gasparilla Island is an $11 \mathrm{~km}$ barrier island just off the southwest coast of Florida (Fig. 1). It has typical low-relief barrier island topography and includes 5 distinct natural communities: beach dune, coastal strand, marine unconsolidated substrate, maritime hammock and estuarine tidal swamp (Florida Natural Areas Inventory 1990). Many of these natural communities have been invaded by exotic plant species, such as Australian pine (Casuarina equisetifolia), Brazilian pepper (Schinus terebinthifolius), beach naupaka (Scaevola sericea) and burrnut (Tribulus cistoides). Gasparilla Island experiences a mild sub-tropical climate, with average summer high temperatures exceeding $30{ }^{\circ} \mathrm{C}$ and average winter high temperatures approximately half that. Precipitation ( $>140 \mathrm{~cm} /$ year) occurs mostly during the JunSep rainy season (http://wildernet.com/). The island includes many neighborhoods of single and multi-family residences as well as resort and condominium developments, and a golf course. The northern portion of the island is in Charlotte County, and the rest is in Lee Coun- 
Figure 1 The study site comprised the Charlotte County portion, approximately the northern quarter, of Gasparilla Island in southwest Florida.

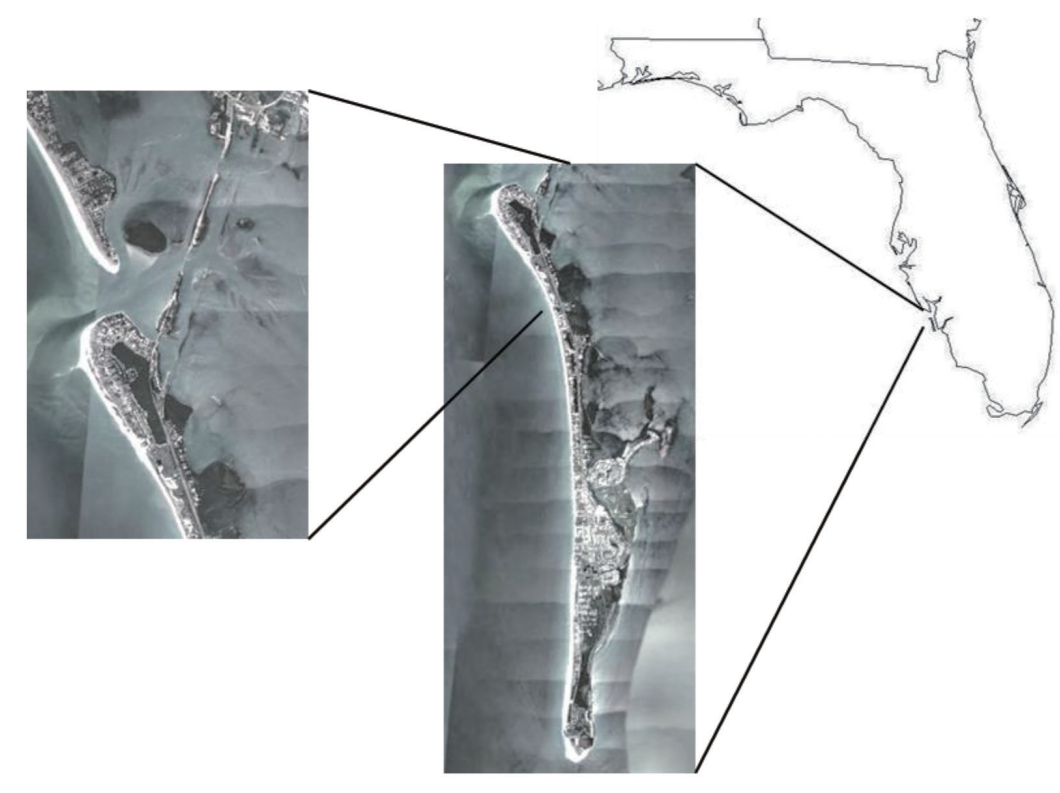

ty. Gasparilla Island State Park (52 ha) is at the southern end of the island and provides a natural protected area for iguanas and other wildlife.

\section{Animals and methods}

Removal efforts throughout Charlotte County started in Feb 2008 and continued each month through 2011, except Dec 2008. In an integrated approach, field personnel simultaneously employed various strategies to remove iguanas. Due to the mixture of habitats, including natural, residential and other developed areas, as well as the behaviors of the animals and restrictions imposed by community residents, great flexibility was required to integrate tools and strategies while optimizing human and material resources for maximizing ctenosaur removal. Trapping strategies included placing baited live traps in shaded areas frequented by iguanas, deploying unbaited live traps in the mouths of gopher tortoise burrows where iguanas had entered, and placing unbaited live traps along the base of walls or other barriers where iguanas traveled. Trappers employed commercial live traps with $2.54 \times 2.54 \mathrm{~cm}$ or $1.27 \times 2.54 \mathrm{~cm}$ mesh and baited with fresh cantaloupe or watermelon. Trappers dispatched captured lizards with a pistol loaded with birdshot or .22 caliber bullets. Field personnel shot iguanas when prudent and safe during regular patrols of the study area using a .22 caliber rifle or air rifle. The dynamic and ever-changing integration of control devices and strategies within a day made the standard $8 \mathrm{~h}$ working day the only practical definition for unit of effort. Thus, we expressed efficacy of the control effort as the number of iguanas removed per day. We included only carcasses actually recovered; some iguanas that were shot retreated to burrows or fell into water and death could not be verified.

For each animal necropsied, we recorded body mass to the nearest gram on a digital scale and snout-vent length (SVL) to the nearest millimeter using a metal ruler. We verified gender by dissection, and assessed reproductive condition of females by counting the number of oviducal eggs or vitellogenic follicles and by weighing the ovary or egg mass. We considered females with broad, convoluted oviducts to have already laid eggs, and we categorized those with straight, narrow oviducts as not yet reproductive. For males, we measured length and width of testes using digital calipers and calculated testes volume following Møller (1991). We summarized the results by month of capture and compared results between years.

We plotted SVL versus month and applied simple linear regression to estimate the rate of growth from hatching to sexual maturity. We considered hatchlings to be animals with SVL $60 \mathrm{~mm}$ or less (Fitch \& Henderson 1978; Fitch \& Hackforth-Jones 1983). In Nicaragua, the sex ratio for $C$. similis is reportedly "strongly skewed 
in favor of females" (Fitch \& Henderson 1978, p. 496). We tested the null hypothesis of equal sex ratios, overall and within size classes using the one-proportion test (Minitab Inc. 2007), with the alternative hypothesis that females constituted $>50 \%$ of the sample. For other statistical analyses we used $t$-tests and one-way analyses of variance as appropriate.

\section{RESULTS}

\section{Iguana removal}

In Charlotte County, during 2008-2011, field personnel removed 9467 iguanas during 616 days of effort. The lowest daily removal rates corresponded to the onset of cooler weather when iguana activity was greatly reduced, and the highest rates reflected the abundance of hatchlings in late summer. The pattern of month-tomonth fluctuation in the removal rate was consistent across years, although amplitudes declined (Fig. 2). Removal rates declined annually across the 4-year study, from 29.6 iguanas/day in 2008 to 1.9 iguanas/day in 2011.

\section{Body size}

Body mass increased nonlinearly as a function of SVL. After log-log transformation, slopes of the linear regression lines for males (logBodyMass $=2.95 \times$ $\log \mathrm{SVL}-4.35 ; R^{2}=0.980$ ) and females (logBodyMass $\left.=3.07 \times \operatorname{logSVL}-4.62 ; R^{2}=0.978\right)$ were statistically indistinguishable $\left(t_{1295}=0.84 ; P=0.40\right.$; Fig. 3$)$. We determined gender for 1462 animals, $57.5 \%$ of which were females (Table 1). Although there was female bias

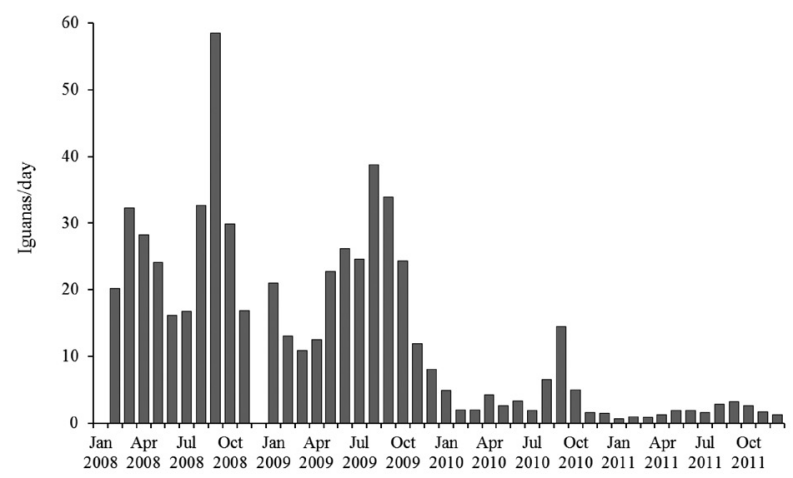

Figure 2 Monthly variation in the number of Ctenosaura similis removed per day during a control program on Gasparilla Island, Charlotte County, Florida, 2008-2011. overall in the population $(P<0.001)$, it was not consistent within SVL size classes, especially in the $>300$ $\mathrm{mm}$ SVL size class, which was $94 \%$ male ( 2 females, 32 males). For each sex, mean body size of animals removed varied across years $(P<0.001)$. For males $\left(F_{3,635}\right.$ $=16.59)$ and females $\left(F_{3,836}=26.00\right)$, mean body size was greatest in 2008, declined in 2009, and then recovered, although not to the original sizes. The maximum size of male iguanas removed annually declined $14.4 \%$ during the study, compared to $3.6 \%$ reduction among females.

Table 1 Sex ratios of Ctenosaura similis collected on Gasparilla Island, Florida, 2008-2011

\begin{tabular}{lllll}
\hline SVL $(\mathrm{mm})$ & $N$ & \% female & $Z$-statistic & $P$ \\
\hline$<100$ & 48 & 63.8 & 1.90 & 0.029 \\
$100-149$ & 275 & 53.1 & 1.03 & 0.153 \\
$150-199$ & 461 & 58.8 & 3.77 & $<0.001$ \\
$200-249$ & 459 & 61.9 & 5.09 & $<0.001$ \\
$250-299$ & 203 & 52.7 & 0.77 & 0.220 \\
$>299$ & 34 & 5.9 & -5.14 & 1.000 \\
Total & 1462 & 57.5 & 5.7 & $<0.001$ \\
\hline
\end{tabular}

For each size class, the null hypothesis of an equal sex ratio was tested against the alternative hypothesis of the female percentage being $>50 \%$, using the 1 proportion test. SVL, snoutvent length.

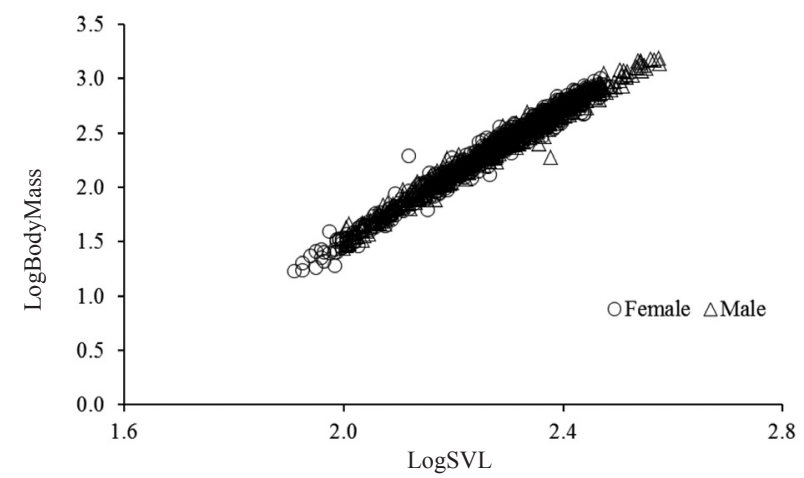

Figure 3 Body mass of $C$. similis $(N=2515)$ increased nonlinearly as a function of snout-vent length (SVL), Gasparilla Island, Charlotte County, Florida, 2008-2011. Males (triangles) and females (circles) displayed statistical identical relationships between body mass and SVL. 


\section{Reproduction and growth}

Reproduction was seasonal. Testes size peaked markedly during Jan-Apr, after which there was rapid testicular regression. Similarly, during Jan-Apr, $67.3 \%$ of all females contained vitellogenic follicles or oviducal eggs, compared to $3.8 \%$ during the rest of the year. The number of females with vitellogenic follicles or oviducal eggs declined annually from 71 in 2008 to 3 in 2011. Females with oviducal eggs occurred from 9 Apr to 1 Jun. During these 3 months, we examined 245 females of reproductive size (>185 mm SVL), 199 (81\%) of which possessed either oviducal eggs, vitellogenic follicles or a convoluted oviduct indicating previous laying. Among females with SVL $\geq 235 \mathrm{~mm}, 99$ of 100 exhibited evidence of reproduction. We found no evidence of multiple clutches per year. Clutch size, as determined by the number of oviducal eggs, averaged $31.6(\mathrm{SE}=1.7)$, and increased with SVL (clutch size $=0.364 \times \mathrm{SVL}-$ 56.564; $\left.R^{2}=0.67, P<0.001, n=56\right)$. Clutch size within size classes did not differ (paired $t$-test, $t=-0.40 ; P$ $=0.707$ ) from that recorded in Nicaragua (Fitch \& Henderson 1978); we recorded only 1 female with SVL > $300 \mathrm{~mm}$ (Table 2). Clutch mass (mean $\pm \mathrm{SE}$ ) as a percentage of female body mass was $18.0 \% \pm 0.7 \%$, and did not vary with SVL $\left(y=0.0345 \times \mathrm{SVL}+9.540 ; R^{2}=\right.$ $0.0378, P=0.849$ ).

We recorded 408 hatchlings (minimum $43 \mathrm{~mm} \mathrm{SVL}$, $2.75 \mathrm{~g}$ body mass), beginning in the last week of Jul $(n=4)$ and extending into Oct $(n=6)$. The remaining $97.5 \%$ of the hatchling iguanas were trapped in AugSep. We plotted SVL versus month each year to identify the appearance of hatchlings in mid-summer (Mesha- ka et al. 2007). We then collapsed these data across the 4 years of the study to produce a composite plot, which reflected a growth rate of approximately $6.8 \mathrm{~mm} / \mathrm{month}$ (Fig. 4).

\section{DISCUSSION}

Characteristics of the invasive $C$. similis population on Gasparilla Island resembled those in the native range in some respects, but differed in others. For example, females with oviducal eggs occurred during 9 Apr to 1 Jun in Florida compared to 4 Feb to 2 Apr in Nicaragua (Fitch \& Henderson 1978). Thus, the very concentrated breeding season characteristic of the species in its native range is manifested in the introduced range, but occurs 2 months later. The sex ratio of $C$. similis in Nica-

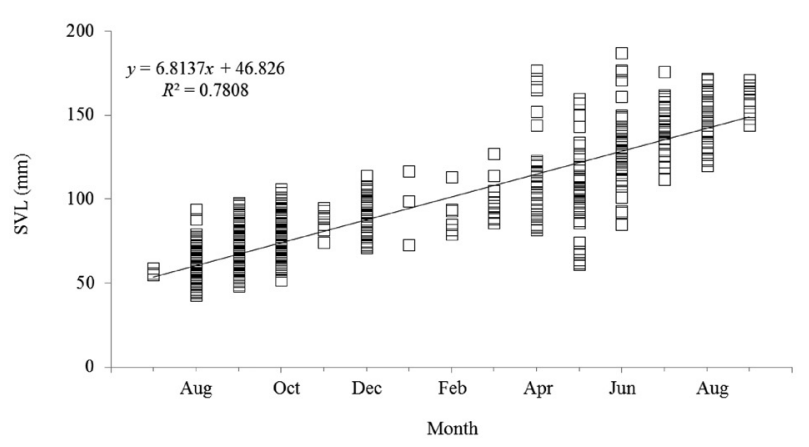

Figure 4 On Gasparilla Island, Florida, C. similis appeared to grow at a rate of approximately $6.8 \mathrm{~mm} / \mathrm{month}$ throughout their first 15 months post-hatching. The graph is a composite comprising the 4 years of the study.

Table 2 Clutch size (oviducal eggs) recorded from female Ctenosaura similis on Gasparilla Island, Florida (this study) and in Nicaragua (Fitch \& Henderson 1978)

\begin{tabular}{|c|c|c|c|c|c|c|}
\hline \multirow[b]{2}{*}{ SVL class $(\mathrm{mm})$} & \multicolumn{3}{|c|}{ Gasparilla Island } & \multicolumn{3}{|c|}{ Nicaragua } \\
\hline & $N$ & Mean & Range & $N$ & Mean & Range \\
\hline $191-250$ & $31^{\dagger}$ & 25.0 & $6-40$ & 16 & 21.7 & $12-27$ \\
\hline $251-269$ & 14 & 33.4 & $5-56$ & 8 & 36.0 & 29-41 \\
\hline $270-284$ & 7 & 40.7 & $5-57$ & 10 & 40.9 & $29-63$ \\
\hline 285-299 & 3 & 50.7 & $44-62$ & 7 & 42.4 & 29-51 \\
\hline $300-310$ & 1 & 34.0 & - & 14 & 51.6 & 30-66 \\
\hline $311-326$ & 0 & - & - & 6 & 61.8 & 49-74 \\
\hline $327-340$ & 0 & - & - & 8 & 69.5 & $59-88$ \\
\hline
\end{tabular}

'Includes 1 animal with snout-vent length $(\mathrm{SVL})=187 \mathrm{~mm}$. Size classes are those used by Fitch and Henderson (1978). 
ragua was female-biased 2:1 (Fitch \& Henderson 1978). Gender bias also occurred on Gasparilla Island where the population was $57 \%$ female. However, just 2 of 393 $(0.51 \%)$ adult females we examined had SVL $>299 \mathrm{~mm}$. This is in contrast to a sample of 283 females from Nicaragua, of which 82 (28.97\%) had SVL $>299 \mathrm{~mm}$ (Fitch $\&$ Henderson 1978). The paucity of large females in our sample relative to Nicaragua could be due to vagaries of sampling, but other explanations for this difference are also plausible.

Ctenosaura similis appears to grow more slowly in Florida than in Central American sites 1500-1800 km farther south, and this, in turn, might be reflected in the observed size distributions. Fitch \& Henderson (1977) report that in Nicaragua hatchlings grew to $>140 \mathrm{~mm}$ SVL and $>80$ g body mass within 6 months. Hatchlings on Gasparilla Island appeared to grow much more slowly, averaging just $91.0 \mathrm{~mm}$ SVL and $21.7 \mathrm{~g}$ body mass after 6 months (Table 3). Growth rate can be affected by various environmental factors, including low temperature and decreased insolation (Fitch 1973). The Florida iguana population is subjected to a very different temperature regime than native $C$. similis (Fig. 5). In particular, historical mean minimum monthly temperatures in Managua, Nicaragua during winter (Dec-Feb) range from 19.7 to $21.2{ }^{\circ} \mathrm{C}$, whereas on Gasparilla Island during the same months mean monthly temperatures range from 10.9 to $12.8{ }^{\circ} \mathrm{C}$ (www.meoweather.com/history). Winter months yielded the lowest rates of removal during the 4-year study (Fig. 2), largely because of the reduced iguana activity. Colder weather not only reduc-

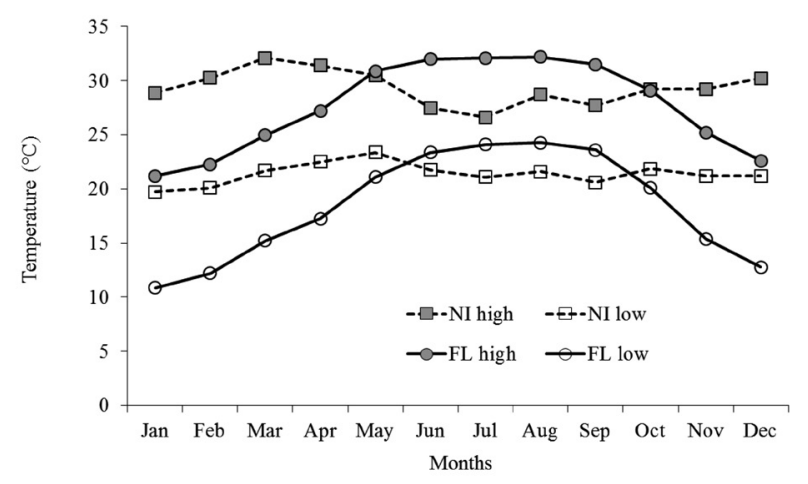

Figure 5 Mean monthly historical maximum and minimum temperatures in the native range (Managua, Nicaragua) and the introduced range (Gasparilla Island, Florida) of C. similis (climate data from www.meoweather.com/history). es activity but also limits growth rate and could retard sexual maturation (Andrews 1976).

Alternatively, lower growth rates on Gasparilla Island could be the result of increased competition for food relative to that in mainland populations in the native range. Animal populations on islands are predicted to experience lower predation, increased intra-specific competition and higher population densities than mainland counterparts (Van Valen 1973; Novosolov et al. 2013). For insular lizard populations, such conditions are expected to produce smaller clutch sizes and larger hatchlings compared to mainland populations (Novosolov et al. 2013). On Gasparilla Island, we found neither to be true. Clutch sizes we recorded were not different from those reported from mainland populations in the native range (Table 2). The range of hatchling sizes reported from Costa Rica (48-58 mm SVL; Fitch \& Hackforth-Jones 1983) and Nicaragua (55-60 mm SVL; Fitch \& Henderson 1978) is commensurate with sizes we recorded (43-69 $\mathrm{mm} \mathrm{SVL}, N=134)$ during the late Jul to early Aug hatching period on Gasparilla Island. We did not measure food availability on the island, and we have no direct evidence of competition for food. Although we cannot rule out intra-specific competition as a contributing factor, we have no indication that it plays a major role in limiting growth rates in the Gasparilla Island population.

Until 2008, the C. similis population on Gasparilla Island was apparently free of significant predation pressure. The large numbers of hatchlings and subadult iguanas removed in 2008 and 2009 attest to the health of the population prior to management actions. However, 4 years of persistent removal efforts greatly reduced the iguana population across all size classes. The removal program will remain a success if control efforts

Table 3 Snout-vent length (SVL) and body mass (mean \pm SE) of juvenile Ctenosaura similis from the cohort that hatched in Aug 2008 and was subsequently collected through Jul 2009 on Gasparilla Island, Florida

\begin{tabular}{llll}
\hline Month & $N$ & SVL $(\mathrm{mm})$ & Body mass $(\mathrm{g})$ \\
\hline Aug 2008 (hatch) & 102 & $63.6 \pm 0.8$ & $7.9 \pm 0.3$ \\
Sep 2008 & 178 & $72.5 \pm 0.8$ & $11.8 \pm 0.4$ \\
Feb 2009 & 6 & $91.0 \pm 5.0$ & $21.7 \pm 3.7$ \\
Mar 2009 & 12 & $98.7 \pm 3.2$ & $30.6 \pm 2.9$ \\
Jul 2009 & 30 & $143.3 \pm 2.5$ & $126.6 \pm 6.8$ \\
\hline
\end{tabular}


are maintained. Relaxation of control efforts will allow the iguana population to recover to pre-treatment levels. Even with potential immigration across the causeway connecting the north end of the island with the mainland (Krysko et al. 2003), the 4-year removal effort demonstrates that an established, otherwise unchecked population of invasive reptiles with high reproductive capacity can be successfully controlled. Other invasive lizard species, such as the Nile monitor (Varanus niloticus L., 1758) and the Argentine tegu (Tupinambis merianae Duméril \& Bibron, 1839), are also well-established in Florida (Krysko et al. 2011b; Pernas et al. 2012). The management outcome documented here for $C$. similis bodes well for ultimate control of these other invasives provided similar dedicated and persistent removal efforts are devised, initiated and maintained.

Ongoing iguana removal efforts also bode well for gopher tortoises, which are found in appropriate habitat throughout the island. Contrary to a previous assessment (McKercher 2001), there are legitimate reasons to believe that iguanas negatively impact gopher tortoises through direct predation (Avery et al. 2009), occupation of tortoise burrows (Engeman et al. 2009) and utilization of food resources (Krysko et al. 2009). As removal efforts deplete the iguana population, there should be a corresponding increase in hatchling and juvenile tortoises observed on Gasparilla Island.

\section{ACKNOWLEDGMENTS}

Funding was provided by the Charlotte County residents of Gasparilla Island and by the National Wildlife Research Center. The project was conceived through discussions with B. U. Constantin and M. L. Christie. We thank K. L. Krysko and T. C. Mathies for insights on iguana anatomy and physiology. M. K. Annala provided laboratory support. K. L. Krysko, S. Meiri, and W. E. Meshaka contributed helpful review comments on the manuscript.

\section{REFERENCES}

Andrews RM (1976). Growth rate in island and mainland anoline lizards. Copeia 1976, 477-82.

Avery ML, Tillman EA, Krysko KL (2009). Gopherus polyphemus (gopher tortoise), Ctenosaura similis (Gray's spiny-tailed iguana) predation. Herpetological Review 40, 435.

Engeman RM, Kennedy M, Constantin BU, Christie ML, Hall PT (2009). Ctenosaura similis (black spinytail iguana), Gopherus polyphemus (gopher tortoise) concurrent burrow use. Herpetological Review 40, 84 .

Fitch HS (1973). A field study of Costa Rican lizards. University of Kansas Science Bulletin 50, 39-126.

Fitch HS, Hackforth-Jones J (1983). Ctenosaura similis (garrobo, iguana negra, ctenosaur). In: Janzen DH, ed. Costa Rican Natural History. University of Chicago Press, Chicago, pp. 393-6.

Fitch HS, Henderson RW (1977). Age and sex differences in the ctenosaur (Ctenosaura similis). Milwaukee Public Museum Contributions to Biology and Geology 11, 1-11.

Fitch HS, Henderson RW (1978). Ecology and exploitation of Ctenosaura similis. University of Kansas Science Bulletin 51, 483-500.

Florida Natural Areas Inventory (1990). Guide to the Natural Communities of Florida. Department of Natural Resources, Tallahassee, FL.

Krysko KL, Burgess JP, Rochford MR et al. (2011a). Verified non-indigenous amphibians and reptiles in Florida from 1863 through 2010: outlining the invasion process and identifying invasion pathways and stages. Zootaxa 3028, 1-64.

Krysko KL, Enge KM, Moler PE (2011b). Atlas of Amphibians and Reptiles in Florida. Final Report, Project Agreement 08013, Florida Fish and Wildlife Conservation Commission, Tallahassee, FL.

Krysko KL, King FW, Enge KM, Reppas AT (2003). Distribution of the introduced black spiny-tailed iguana (Ctenosaura similis) on the southwestern coast of Florida. Florida Scientist 66, 74-9.

Krysko KL, Larson KW, Diep D, Abellana E, McKercher ER (2009). Diet of the nonindigenous black spinytailed iguana, Ctenosaura similis (Gray, 1831) (Sauria: Iguanidae), in southern Florida. Florida Scientist 72, 48-58.

McKercher E (2001). Ctenosaura pectinata (Iguanidae) on Gasparilla Island, Florida: colonization, habitat use, and interactions with Gopherus polyphemus (MS Thesis). University of Florida, Gainesville, Florida, USA.

Meshaka WE Jr (2011). A runaway train in the making: the exotic amphibians, reptiles, turtles and crocodilians of Florida. Monograph 1, Herpetological Conservation and Biology 6, 1-101.

Meshaka WE Jr, Smith HT, Golden E et al. (2007). Green iguanas: the unintended consequence of sound 
wildlife management practices in a south Florida park. Herpetological Conservation and Biology 2, 149-56.

Minitab Inc. (2007). Minitab Statistical Software, Release 15 for Windows, State College, Pennsylvania.

Møller AP (1991). Sperm competition, sperm depletion, paternal care and relative testis size in birds. American Naturalist 137, 882-906.

Novosolov M, Raia P, Meiri S (2013). The island syndrome in lizards. Global Ecology and Biogeography 22, 184-91.

Pernas T, Giardina DJ, McKinley A, Parns A, Mazzotti FJ (2012). First observations of nesting by the Argentine black and white tegu, Tupinambis merianae, in south Florida. Southeastern Naturalist 11, 765-70.

Reed M (2006). Non-native iguanas sink their claws into Fla. island. USA Today 26 Jun [Cited 2 Feb
2012.] Available from URL: http://www.usatoday. com/news/nation/2006-06-26-florida-iguanas_x.htm

Savage JM (2002). The Amphibians and Reptiles of Costa Rica: A Herpetofauna between Two Continents, between Two Seas. University of Chicago Press, Chicago, IL.

Stephen C, Pasachnik S, Reuter A, Mosig P, Ruyle L, Fitzgerald L (2011). Survey of status, trade and exploitation of Central American iguanas. [Cited $17 \mathrm{Apr}$ 2012.] Available from URL: http://www.iguanafoundation.org/files/8f61115e-ae8a-49ef-bc6b-90c2bffdbac2.PDF

Townsend JH, Krysko KL, Enge KM (2003). The identity of spiny-tailed iguanas, Ctenosaura, introduced to Florida, USA. Herpetozoa 16, 67-72.

Van Valen LM (1973). A new evolutionary law. Evolutionary Theory 1, 1-30. 